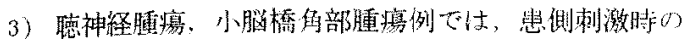

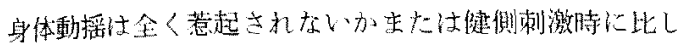

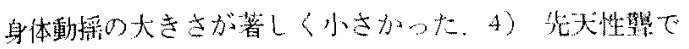

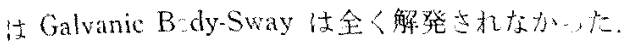

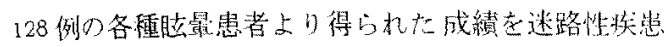

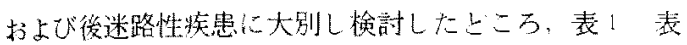
20 如き結果とな，た。广おち迷路性疾患82例の5 万 Galvanic Test にて正常店在示したもの73例上約89\% が正常倠を示しているのに刘し（衰1），後迷路性疾患

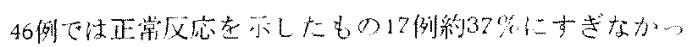

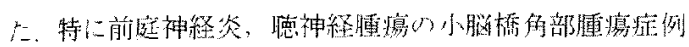

『圷上んしの症例で琶常走示した(表2)。

結論: Galvanic Body-Sway Test は, 像来上りく 游られている Galvanic Nystagmus Test E比L刺激

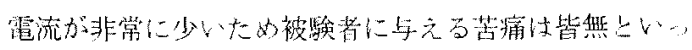
てよく，日学检植しして充分用い得る检查法上いえる。

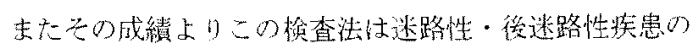

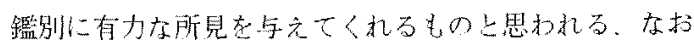

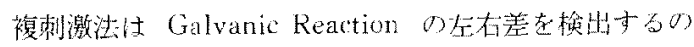
に有奻な手段で古るといるる。

( B $80-1290-24522)$

\title{
72. 正常乳児の聴覚の発達
}

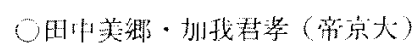

生来蜼㯖老持つ子供仕，1万人につき数名以下しか生

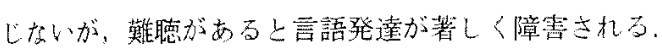

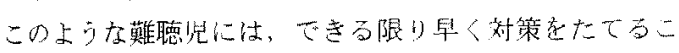

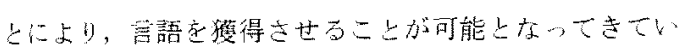

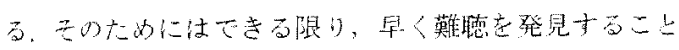

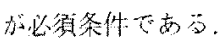

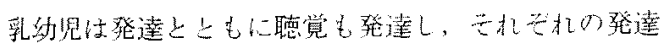
段障で，音に対する反応が買なる。各種の原因に上る発

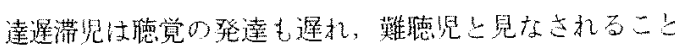

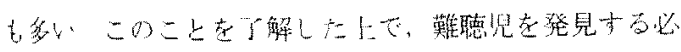

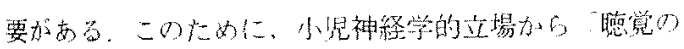
発澾」加るこ上が重要でかる。

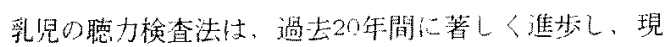

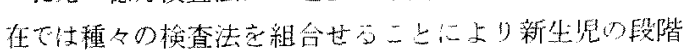
から検查ができるようになった，最近で恃著者らの外来

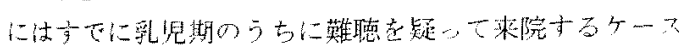
が目立のてきているが、このこ上は難腮児の早期り八ヒ

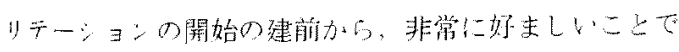

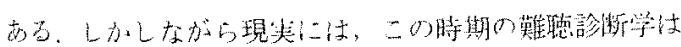

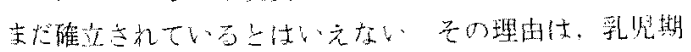

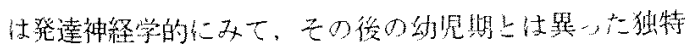

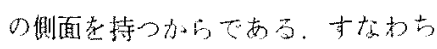

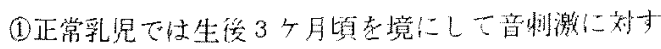
万反店梂式が变る。

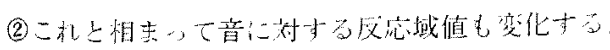

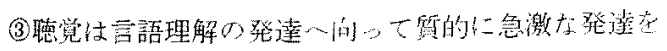

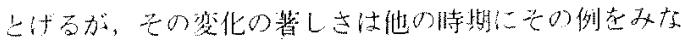
.

このような乳筧期特有の発逆的側面はいうまでしなく

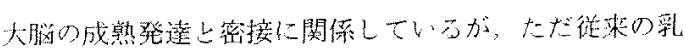

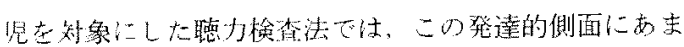

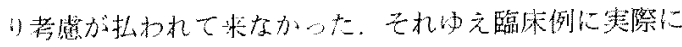

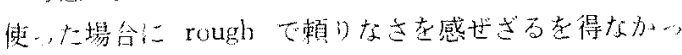

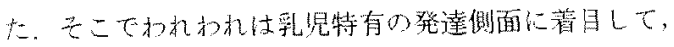

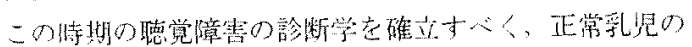

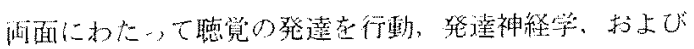

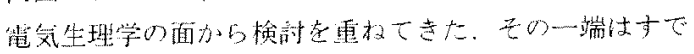
に聴觉の発達梌查法しして報告しできが，今回は正掌

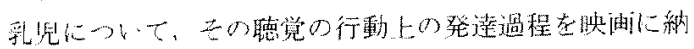

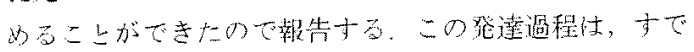

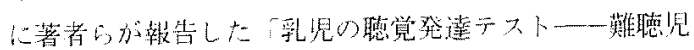
早期発見のためにしよく一致した。

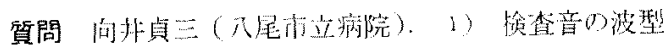

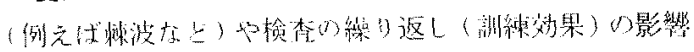

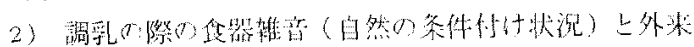

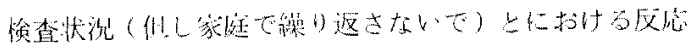

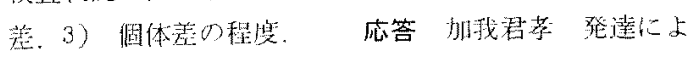
る個人善は，甘いぜいブラスマイナス４月くらいにし

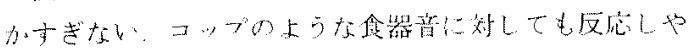

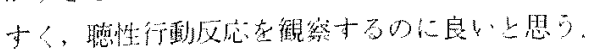

(B 80-1291-23992 